\title{
PENERAPAN MODEL PEMBELAJARAN QUANTUM LEARNING UNTUK MENINGKATKAN HASIL BELAJAR IPA PESERTA DIDIK KELAS V SEKOLAH DASAR
}

\author{
Arifin Djenawa \\ Program Studi Pendidikan Guru Sekolah Dasar \\ Universitas Muhammadiyah Kupang \\ E-mail: adjenawa@gmail.com
}

\begin{abstract}
Abstrak
Penelitian ini merupakan penelitian tindakan kelas. Sampelnya berjumlah 31 orang. Teknik pengumpulan data yang digunakan dalam penelitian ini adalah observasi, tes dan dokumentasi. Data kualitatif yang dikumpulkan akan dianalisis dengan tiga tahap kegiatan yaitu: (1) reduksi data, (2) menyajikan data, dan (3) menarik kesimpulan dan verifikasi data. Hasil Pada siklus I dengan rata-rata hasil belajar siswa mencapai 70,29 dengan persentase hasil belajar secara klasikal sebesar 70,29\%. Dari 31 orang siswa, 21 diantaranya telah mencapai nilai diatas KKM. Pada siklus I ketuntasan belajar mencapai $70,29 \%$. Sedangkan pada siklus II rata-rata hasil belajar siswa mencapai 85,45 dengan persentase hasil belajar secara klasikal sebesar $85,45 \%$. Sehingga rata-rata hasil belajar siswa meningkat sebesar 15,16. Dari 31 orang siswa, semuanya telah mencapai nilai diatas KKM sehingga ketuntasan belajar mencapai $100 \%$. Dengan demikian pada siklus II, hasil belajar siswa dan persentase hasil belajar secara klasikal telah mencapai peningkatan.
\end{abstract}

Kata kunci:

Model quantum

learning, hasil belajar

\begin{abstract}
This research is a classroom action research. The sample is 31 people. Data collection techniques used in this study were observation, testing and documentation. Qualitative data collected will be analyzed with three stages of activities, namely: (1) data reduction, (2) presenting data, and (3) drawing conclusions and verification of data. Results In the first cycle with an average student learning outcomes reached 70.29 with the percentage of classical learning outcomes of $70.29 \%$. Of the 31 students, 21 of them have achieved grades above the KKM. In the first cycle learning completeness reached $70.29 \%$. While in the second cycle the average student learning outcomes reached 85.45 with the percentage of classical learning outcomes of $85.45 \%$. So the average student learning outcomes increase by 15.16. Of the 31 students, all of them had achieved grades above the KKM so that learning completeness reached $100 \%$. Thus in the second cycle, student learning outcomes and the percentage of learning outcomes in a classical manner has improved.
\end{abstract}

Keywords: Quantum learning model, learning outcomes 


\section{PENDAHULUAN}

Pendidikan Sekolah Dasar merupakan pendidikan dasar yang memegang peran penting sebagai pembentuk kepribadian anak dan pola pikir anak. Di jenjang pendidikan Sekolah Dasar anak diajarkan berbagai ilmu sebagai pondasi anak untuk menjalani pendidikan dijenjang selanjutnya. Ilmu Pengetahuan Alam (IPA) merupakan mata pelajaran pokok yang diajarkan pada jenjang pendidikan Sekolah Dasar. Pada mata pelajaran Ilmu Pengetahuan Alam (IPA) siswa diajarkan berbagai konsep-konsep dan gejala-gejala yang berkaitan dengan alam sekitar. Siswa diajak untuk memahami konsepkonsep dan gejala-gejala alam melalui berbagai cara. Misalnya, dengan cara pengamatan, praktikum, mengukur, menganalisis, dll.

IPA merupakan mata pelajaran wajib di sekolah dasar yang bertujuan tidak hanya mengembangkan kognitif, afektif dan psikomotorik siswa namun juga sebagai bekal siswa dalam mengenal alam di lingkungan sekitarnya dan melatih siswa mengambil keputusandalammenyelesaikansuatumasalah. Guru memiliki peran yang sangat penting untuk mencapai tujuan tersebut dengan merancang suatu proses pembelajaran yang efektif. Suatu pembelajaran yang efektif tercermin dari hasil belajar yang di dapatkan oleh siswa. IPA merupakan ilmu yang mempelajari tentang dunia zat, baik makhluk hidup maupun benda mati yang diamati (Triyanto, 2012).

Pembelajaran IPA adalah suatu mata pelajaran dengan materi pembelajaran yang masih bersifat abstrak bagi peserta didik tingkat SD yang masih konkrit pemikirannya. Salah satu upaya untuk meningkatkan kemampuan peserta didik terhadap pemahaman IPA dilihat dari segi proses, maka diperlukan suatu model pembelajaran menuju ke arah yang lebih baik yaitu pembelajaran yang mencakup suatu proses interaksi positif antara guru dan peserta didik. Peserta didik dapat membangkitkan kemampuan untuk berkomunikasi dalam pembelajaran, menyediakan stimulus belajar, mengaktifkan respon murid, memberikan balikan dengan segera dan melatih peserta didik untuk menyimpulkan hasil pembelajaran secara mandiri.

Menurut Sulistyorini (2007: 9) menyatakan bahwa pada hakikatnya, IPA dapat dipandang dari segi produk, proses dan dari segi pengembangan sikap. Artinya, belajar IPA memiliki dimensi proses, dimensi hasil (produk), dan dimensi pengembangan sikap ilmiah. Ketiga dimensi tersebut bersifat saling terkait. Ini berarti bahwa proses belajar mengajar IPA seharusnya mengandung ketiga dimensi IPA tersebut. IPA membahas tentang gejala-gejala yang terjadi di alam semesta ini yang disusun secara sistematis berdasarkan hasil percobaan dan pengamatan manusia. Hal ini sebagaimana yang dikemukakan oleh Powler (dalam Samatowa, 2011:3) bahwa IPA merupakan ilmu yang berhubungan dengan gejala alam dan kebendaan yang sistematis yang tersusun secara teratur, berlaku umum yang berupa kumpulan dari hasil observasi dan eksperimen/sistematis (teratur) artinya pengetahuan itu tersusun dalam suatu sistem, tidak berdiri sendiri, satu dengan lainnya saling berkaitan, saling menjelaskan sehingga seluruhnya merupakan satu kesatuan yang utuh, sedangkan berlaku umum artinya pengetahuan itu tidak hanya berlaku oleh seseorang atau beberapa orang dengan cara eksperimentasi yang sama akan memperoleh hasil yang sama atau konsisten. Selanjutnya Winaputra (dalam Samatowa, 2011:3) juga mengemukakan bahwa IPA tidak hanya merupakan kumpulan pengetahuan tentang benda atau makhluk hidup, tetapi memerlukan kerja, cara berpikir, dan cara memecahkan masalah. 
Berdasarkan hasil pengamatan terhadap aktivitas riil di SD Muhammadiyah 2 Kupang kegiatan belajar mengajar di sekolah pada umumnya cenderung tidak menarik, sehingga beberapa pelajaran ditakuti dan selalu dianggap sulit oleh peserta didik, termasuk di dalamnya adalah IPA. Hal ini dikarenakan model pembelajaran yang tidak menarik (ceramah). Dalam proses belajar peserta didik, tidak dipungkiri lagi bahwa pembelajaran IPA di Sekolah Dasar belum sesuai dengan yang diharapkan. Guru-guru di SD kebanyakan belum memahami dengan benar cara mengajar IPA dengan benar dan dilakukan dalam suasana menyenangkan. Berbagai macam keluhan dalam pembelajaran IPA di SD seperti; malas belajar, membosankan (jenuh), kurang bergairah, tidak menarik, dan keluhan-keluhan lain dari para peserta didik, adalah permasalahan mendasar yang harus segera diatasi.

Penguasaan materi IPA siswa dapat diketahui melalui hasil belajar yang diperoleh siswa. Hasil belajar merupakan gambaran tingkat kemajuan siswa dalam belajar yang berupa skor atau angka. Hasil belajar inilah yang biasanya menjadi dasar tolak ukur keberhasilan guru dalam pembelajaran. Tingkat pemahaman siswa diukur melalui nilainilai yang diperoleh siswa saat diberi soal maupun saat ujian. Namun sebaiknya tidak hanya hasil belajar yang dijadikan tolak ukur keberhasilan dalam pembelajran IPA, namun masih terdapat beberapa hal yang perlu diperhatikan dalam IPA yang dapat dijadikan penilaian. Hasil belajar adalah merupakan hasil dari suatu interaksi tindakan belajar dan tindakan mengajar (Dimiyanti dan Mujiono, 2006)

Atas dasar keluhan dalam pembelajaran IPA di SD, tidak mengherankan dalam beberapa tahun terakhir ini di Indonesia muncul berbagai falsafah dan metodologi pembelajaran yang dipandang baru meskipun sebenarnya sudah ada sebelumnya. Beberapa diantaranya adalah pembelajaran konstruktivis, pembelajaran kooperatif, pembelajaran terpadu, pembelajaran aktif, pembelajaran kontekstual (Contextual Teaching and Learning, CTL), pembelajaran berbasis projek (project based learning), pembelajaran berbasis masalah (problem based learning), pembelajaran interaksi dinamis, dan pembelajaran kuantum (quantum learning).

Upaya memperbaiki kondisi pembelajaran IPA seperti di atas dapat dilakukan dengan menggunakan model pembelajaran kuantum (quantum learning) adalah sebuah pilihan tepat bagi guru SD guna meningkatkan hasil belajar peserta didik dalam belajar IPA. Lebih dari itu, model pembelajaran ini menjadikan pengajaran dan pembelajaran lebih menggairahkan. Peneliti merasa yakin bahwa model pembelajaran ini sangat cocok untuk diterapkan dalam proses pembelajaran IPA di SD. Penggunaan metode pengajaran yang tepat diharapkan dapat meningkatkan hasil belajar peserta didik dan pemahamannya terhadap materi.

Fauziah (2013) mengatakan bahwa model quantum learning merupakan model pembelajaran yang ideal karena menekankan kerja sama antar peserta didik dan guru untuk mencapai tujuan bersama. Model pembelajaran ini juga merupakan salah satu model pembelajaran yang berusaha menciptakan lingkungan belajar yang efektif dengan cara menggunakan unsur yang ada pada peserta didik dan lingkungan belajar melalui interaksi yang terjadi di dalam kelas, sehingga memungkinkan peserta didik dapat belajar secara optimal, yang pada gilirannya dapat meningkatkan pemahaman serta hasil belajar peserta didik.

Model pembelajaran kuantum (quantum learning) merupakan solusi yang dapat digunakan untuk meningkatkan hasil belajar peserta didik dalam proses pembelajaran. 
Metode pembelajaran kuantum (quantum learning) dapat menciptakan suasana belajar yang menyenangkan dengan segala nuansanya, demokrasi, penanaman konsep yang diperoleh dari hasil penyelidikan, penyimpulan serta meningkatkan motivasi peserta didik dalam belajar, membangkitkan minat dan partisipasi, serta meningkatkan pemahaman materi. Hasil belajar adalah merupakan hasil dari suatu interaksi tindakan belajar dan tindakan mengajar (Dimiyanti dan Mujiono, 2006). Pada proses pembelajaran model quantum learning terjadi penyelarasan dan pemberdayaan komunitas belajar, sehingga guru dan peserta didik yang terlibat dalam proses pembelajaran sama-sama merasa senang dan saling bekerja sama untuk mencapai hasil yang maksimal.

Lingkungan yang mendukung dan proses pembelajaran yang menyenangkan dan menggairahkan dapat menciptakan serta meningkatkan hasil belajar siswa SD untuk belajar IPA. Sehingga keluhan-keluhan seperti bosan, jenuh, kurang bergairah dan tidak menarik yang selama ini sering didengungkan dari peserta didik dalam proses pembelajaran IPA dapat teratasi melalui model pembelajaran ini.

\section{METODE}

Penelitian ini mengikuti tahap-tahap penelitian tindakan sebagaimana dikemukakan Kemmis dan Taggart. Berikut ini adalah model penelitian yang menggambarkan beberapa putaran secara berkelanjutan.

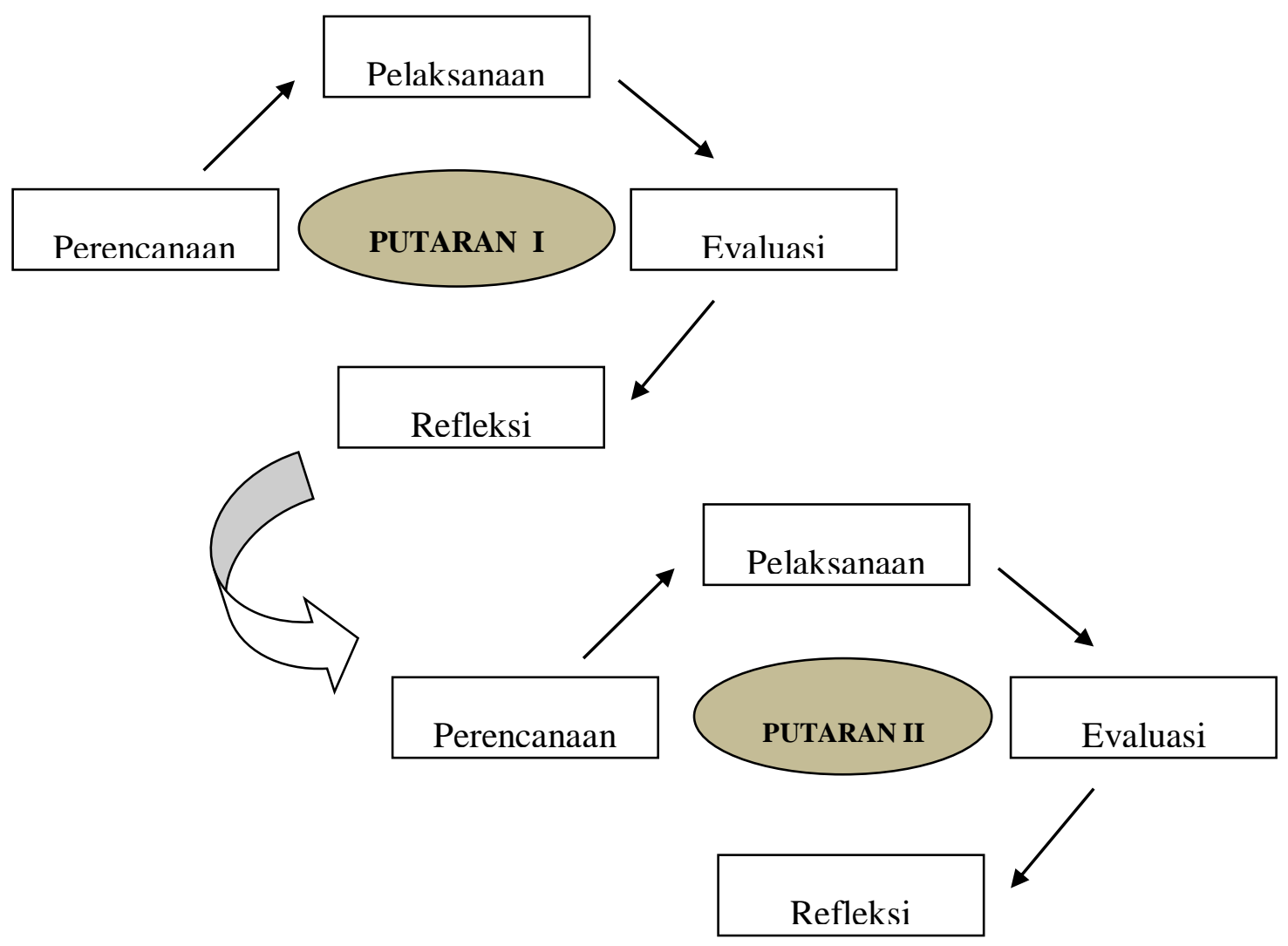

Gambar 1. Model Penelitian Tindakan Kelas Dua Siklus (Agung, A.A. Gede, 2010). 
Gambar diatas merupakan alur penelitian yang akan dilaksanakan. Kegiatan penelitian di mulai dari merumuskan suatu permasalahan yang akan dikaji. Setelah masalah dirumuskan secara jelas, 1) dibuatkan suatu perencanaan tindakan yang dilakukan untuk mengatasi permasalahan tersebut, 2) selesai membuat perencanaan tindakan maka dilanjutkan dengan pelaksanaan tindakan untuk mengimplementasikan rencana tindakan yang sudah disusun tersebut, 3) melaksanakan observasi dan evaluasi terhadap kegiatan yang telah dilaksanakan, 4) selanjutnya pada akhir siklus dilakukan refleksi terhadap hasil penelitian yang telah dilakukan. Apabila tujuan dari penelitian yang dilakukan belum tercapai maka selanjutnya dilaksanakan siklus selanjutnya sampai tujuan penelitian tercapai.

Data yang dikumpulkan dalam penelitian ini yaitu data kuantitatif dan data kualitatif. Menurut Margono (2009: 156) data kuantitatif merupakan data yang berkenaan dengan jumlah atau kuantitas, yang dapat dihitung dan disimbolkan dengan ukuran-ukuran kuantitas tertentu. Sedangkan data kualitatif berkenaan dengan dengan nilai kualitas seperti baik, sedang, kurang, dan lain-lain. Teknik pengumpulan data yang digunakan dalam penelitian ini adalah observasi, tes dan dokumentasi. Data kualitatif yang dikumpulkan akan dianalisis dengan tiga tahap kegiatan yaitu: (1) reduksi data, (2) menyajikan data, dan (3) menarik kesimpulan dan verifikasi data. Sesuai prosedur suatu penelitian tindakan kelas, dalam hal ini dilakukan beberapa kegiatan yaitu refleksi awal dan kegiatan pelaksanaan tindakan. Berikut ini akan di uraikan secara lebih mendetail mengenai masing-masing kegiatan tersebut.

Kegiatan Pelaksanaan Tindakan

Putaran I

Dalam putaran ini dilakukan beberapa kegiatan sebagai berikut:

a. Perencanaan Tindakan: Dalam tahap perencanaan tindakan dilaksanakan beberapa kegiatan, yaitu: 1) Menyamakan persepsi dengan guru mengenai model pembelajaran kuantum; 2) Menentukan materi ajar yang akan dikaji, yaitu materi pelajaran IPA; 3) Menyusun RPP dan LKS yang sesuai dengan model pembelajaran kuantum; 4) Menyusun instrumen penelitian berupa tes hasil belajar; 5) Menyusun lembar observasi; 6) Merancang media pembelajaran yang sesuai dengan materi pelajaran.

b. Pelaksaan Tindakan: Pada tahap pelaksanaan tindakan ini, guru melaksanakan pembelajaran berdasarkan rencana pembelajaran yang telah disusun pada tahap perencanaan yaitu pembelajaran yang mengacu pada penerapan model pembelajaran kuantum.

c. Observasi dan Evaluasi: Kegiatan yang dilakukan pada tahap ini adalah sebagai berikut: 1) Observasi terhadap pelaksanaan tindakan, yaitu mencatat segala kejadian terkait dengan proses pembelajaran; 2) Memberikan pos-tes 1 pada akhir putaran I untuk mengetahui hasil belajar siswa setelah dilaksanakan tindakan I.

d. Refleksi: Refleksi dilakukan berdasarkan hasil observasi dan evaluasi selama proses pembelajaran. Tujuannya adalah untuk mengidentifikasi hasil tindakan pada putaran I, sejauh mana hasil yang dicapai, kekurangan atau kendala yang dialami. Permasalahan yang timbul didiskusikan dengan guru bidang studi IPA dan dicari 
alternatif pemecahannya, yang selanjutnya akan dirumuskan suatu tindakan yang lebih baik yang dapat dilaksanakan pada putaran II.

Penelitian ini dilaksanakan di kelas V SD Muhammadiyah 2 Kupang dengan jumlah siswa sebanyak 31 orang. Indikator keberhasilan proses pada penelitian ini adalah semua indikator aktivitas belajar siswa dalam proses pembelajaran yang dikatakan berhasil apabila minimal $75 \%$ dengan kualifikasi baik berdasarkan pedoman observasi guru. Adapun indikator keberhasilannya berupa hasil belajar siswa yang jika $75 \%$ atau lebih dari jumlah siswa yang mengikuti proses pembelajaran berhasil mendapat nilai $>75$.

\section{HASIL DAN PEMBAHASAN \\ Hasil:}

Pada siklus I diperoleh rata-rata hasil belajar siswa sebesar 70,29. Dari 31 siswa, jumlah siswa yang mencapai nilai sesuai atau lebih dari KKM sebanyak 21 orang (68\%) dan jumlah siswa yang mencapai nilai dibawah KKM sebanyak 10 orang (32\%). Dengan demikian persentase ketuntasan belajar siswa pada siklus I sebesar $68 \%$ dan persentase hasil belajar secara klasikal sebesar $70 \%$.

Berdasarkan data tersebut hasil belajar siswa belum memenuhi kriteria dan tujuan dari penelitian ini belum tercapai yaitu belum adanya peningkatan hasil belajar IPA siswa setelah diterapkannya model pembelajaran kuantum dan ditambah ketuntasan belajar siswa belum sempurna dikarenakan masih ada 10 siswa yang mendapatkan nilai dibawah KKM. Oleh karena itu peneliti akan mengadakan siklus II dengan memperhatikan kendala atau permasalahan yang terjadi pada siklus I, sehingga pada siklus II permasahan tersebut dapat diatasi dan tujuan dari penelitian ini bisa tercapai.

Rata-rata hasil belajar siswa pada siklus II sebesar 85,45. Dari 31 siswa, jumlah siswa yang mencapai nilai sesuai atau lebih dari KKM sebanyak 31 orang dan tidak ada siswa yang memperoleh nilai dibawah KKM. Dengan demikian persentase ketuntasan belajar siswa mencapai $100 \%$ dan persentase hasil belajar secara klasikal sebesar $85,45 \%$. Berdasarkan data tersebut, maka ketuntasan belajar siswa dan persentase hasil belajar siswa secara klasikal telah mengalami peningkatan sebesar 15,16\%.

Berdasarkan hasil refleksi siklus II, nilai hasil belajar siswa telah mencapai nilai diatas KKM dengan ketuntasan belajar siswa dan persentase hasil belajar secara klasikal telah mengalami peningkatan. Oleh karena itu, penelitian ini dapat dinyatakan telah berhasil dan siklus tidak dilanjutkan kembali.

\section{Pembahasan:}

Pada siklus I pembelajaran belum mencapai indikator keberhasilan yang direncanakan. Hal tersebut disebabkan masih kurang baiknya pengelolaan kelas oleh guru dan kurang relefannya apersepsi danmateri yang diajarkan. Selain itu guru kurang maksimal dalam membimbing dan menanamkan konsep pembelajaran pada siswa sehingga berdampak pada pemahaman siswa yang masih kurang terhadap materi yang diajarkan. Selain itu ada beberapa siswa yang belum dapat menjawab pertanyaan ketika ditunjuk. Hasil penelitian pada tindakan siklus I menunjukkan bahwa tingkat keberhasilan proses dan hasil belajar belum mencapai indikator keberhasilan yang ditetapkan sehingga perlu dilanjutkan pada siklus II dengan beberapa perbaikan dalam pelaksanaan pembelajaran. 
Pada siklus II indikator keberhasilan yang ditetapkan telah tercapai karena siswa lebih memahami materi yang diajarkan, hal tersebut terlihat dengan keberanian siswa menjawab pertanyaan yang diajukan oleh guru dan siswa sudah mampu melaksanakan indikator-indikator pembelajaran dengan menggunakan model pembelajaran quantum learning. Selain itu, guru juga telah menerapkan langkah-langkah model pembelajaran quantum learning dengan sangat baik.

Melihat peningkatan hasil belajar siswa dalam pembelajaran IPA yang menerapkan model pembelajaran quantum learning, dapat diketahui bahwa model pembelajaran quantum learning sangat memberikan kontribusi yang positif dalam proses pembelajaran dan hasil belajar siswa yang optimal serta sangat baik digunakan dalam peningkatan kualitas pembelajaran khususnya di Sekolah Dasar.

\section{KESIMPULAN}

Berdasarkan hasil penelitian dan pembahasan yang telah diuraikan sebelumnya, maka dapat diambil simpulan sebagai berikut.

Pembelajaran quantum learning dapat meningkatkan hasil belajar IPA siswa kelas V SD. Pada siklus I rata-rata hasil belajar siswa mencapai 70,29 dengan persentase hasil belajar secara klasikal sebesar 70,29\%. Dari 31 orang siswa, 21 diantaranya telah mencapai nilai diatas KKM. Pada siklus I ketuntasan belajar mencapai 70,29\%. Sedangkan pada siklus II rata-rata hasil belajar siswa mencapai 85,45 dengan persentase hasil belajar secara klasikal sebesar $85,45 \%$. Sehingga rata-rata hasil belajar siswa meningkat sebesar 15,16 . Dari 31 orang siswa, semuanya telah mencapai nilai diatas KKM sehingga ketuntasan belajar mencapai 100\%. Dengan demikian pada siklus II, hasil belajar siswa dan persentase hasil belajar secara klasikal telah mencapai peningkatan.

Penelitian dihentikan pada siklus II, karena pada siklus II hasil belajar siswa kelas V SD Muhammadiyah 2 Kupang telah meningkat.

\section{DAFTAR PUSTAKA}

Agung, A.A. Gede. 2010. Penelitian Tindakan Kelas (Teori dan Analisis Data dalam PTK). Makalah disajikan dalam workshop Jurusan Pendidikan Guru Sekolah Dasar FIP Undiksha, Singaraja 27 september 2010.

Arikunto, Suharsini, dkk. 2007. Penelitian Tindakan Kelas. Jakarta: PT Bumi Aksara.

Dimiyati dan Mudjiono. 2006. Belajar dan Pembelajaran.Jakarta:RinekaCipta.

Fauziah, N., M. Masykuri., \& A. Nugroho. 2013. Studi Komparasi Metode Pembelajaran Student Teams Achievement Division (STAD) Menggunakan Peta Pikiran (Mind Mapping) dan Peta Konsep (Concept Mapping) Terhadap Prestasi Belajar Peserta didik pada Materi Pokok Sistem Periodik Unsur Peserta didik Kelas X Semester Ganjil SMA Negeri Kebakkramat Tahun Pelajaran 2012/2013. Jurnal Pendidikan Kimia. 2(2):132-139. [diakses 24-1-2015] 
Triyanto. (2012). Model Pembelajaran Terpadu Konsep, Strategi, dan Implementasinya Dalam KTSP. Jakarta: Bumi Aksara.

Margono. 2009. Metodologi Penelitian Tindakan Komponen MKDK. Jakarta: Rineka Cipta.

Samatowa, Usman. 2010. Pembelajaran IPA di Sekolah Dasar.Jakarta: PT Indeks

Sulistyorini, Sri, dan Suparno. 2007. Model Pembelajaran IPA Sekolah Dasar dan

Penerapannya Dalam KTSP. Yogyakarta: Tiara Wacana 
